\title{
KONTRIBUSI PENDAPATAN INDUSTRI RUMAH PANGGUNG TERHADAP PENDAPATAN RU- MAH TANGGA MASYARAKAT DI DESA WOLOAN SATU UTARA KEC. TOMOHON BARAT
}

\author{
Yosua Kalangi \\ Paulus A. Pangemanan \\ Juliana R. Mandei \\ Caroline B. D. Pakasi
}

\begin{abstract}
This study aims to determine the contribution of revenue from industrial houses on stilts on household income. This research was conducted for four months starting in February 2015 to May 2015 in the village of Woloan One North district. Tomohon West. The population in this study was people who became workers in home industries stage. Of the population of 30 samples has taken using simple random sampling method. In this study, the data used are primary and secondary data obtained from the relevant agencies, namely the Village district office Woloan One District Tomohon North West. The data is processed using descriptive analysis. The results showed that the contribution of revenue from the industry is a stilt house by $84 \%$ and are potentially in employment. The amount of revenue contribution from home industry is very influential stage in household income, while contributions outside the home industry are less influential stage in household income. For the second job in industry stilt house can be made in the main work as a source of household income communities Woloan One Village North.
\end{abstract}

Keywords: Contributions, Income and Labour

\section{ABSTRAK}

Penelitian ini bertujuan untuk mengetahui kontribusi pendapatan dari industri rumah panggung terhadap pendapatan rumah tangga. Penelitian ini dilakukan selama empat bulan mulai pada bulan februari 2015 hingga mei 2015 di Desa Woloan Satu Utara Kec. Tomohon Barat. Yang menjadi populasi dalam penelitian ini adalah masyarakat yang menjadi tenaga kerja di industri rumah panggung. Dari populasi tersebut di ambil 30 sampel dengan menggunakan metode simple random sampling. Pada penelitian ini data yang digunakan adalah data primer dan sekunder yang diperoleh dari instansi yang terkait yaitu kantor kelurahan Desa Woloan Satu Utara Kecamatan Tomohon Barat. Data tersebut diolah menggunakan metode penelitian analisis deskriptif. Hasil penelitian menunjukan bahwa kontribusi pendapatan dari industri rumah panggung adalah sebesar $84 \%$ dan sangat berpotensi dalam penyerapan tenaga kerja. Besarnya kontribusi pendapatan dari industri rumah panggung sangat berpengaruh dalam pendapatan rumah tangga sedangkan kontribusi di luar industri rumah panggung kurang berpengaruh dalam pendapatan rumah tangga. Untuk itu pekerjaan sampingan pada industri rumah panggung dapat di jadikan pekerjaan utama sebagai sumber pendapatan rumah tangga masyarakat Desa Woloan Satu Utara.

Kata Kunci :Kontribusi, Pendapatan dan Tenaga Kerja

\section{PENDAHULUAN}

\section{Latar Belakang}

Pembangunan ekonomi merujuk kepada aktivitas untuk meningkatkan taraf ekonomi sebuah negara dan rakyatnya supaya dapat hidup dengan lebih sempurna (Nain dan Yusoff, 2003). Di Indonesia pembangunan ekonomi dipacu melalui upaya mendorong pertumbuhan ekonomi dan sebaliknya pertumbuhan ekonomi akan berdampak untuk memperlancar proses pembangunan ekonomi. Ada 
beberapa faktor yang mempengaruhi pertumbuhan dan pembangunan ekonomi.Faktor tersebut diantaranya adalah sumber daya alam, sumber daya manusia, sumber daya modal, dan keahlian atau kewirausahaan.

Pemenuhan kebutuhan manusia yang tidak terbatas, manusia dituntut untuk berusaha secara maksimal guna memenuhi kebutuhannya yang merupakan syarat kelangsungan hidup.Untuk memenuhi kebutuhan tersebut manusia harus bekerja.Dengan bekerja manusia dapat memperoleh pendapatan untuk mencukupi kebutuhan diri sendiri dan juga keluarga, rendahnya tingkat hidup atau kemakmuran suatu ditentukan oleh pendapatan perkapita.Pendapatan perkapita adalah seluruh pendapatan dibagi jumlah seluruh penduduk.Jadi meningkatnya kesejahteraan masyarakat dapat diukur dengan tinggi rendahnya pendapatan perkapita.Industri merupakan salah satu strategi pembangunan nasional yang bertujuan mewujudkan bangsa yang maju dan mandiri serta sejahtera lahir batin, sebagai landasan bagi pembangunan tahap berikutnya menuju masyarakat adil dan makmur berdasarkan Pancasila dan Undang-Undang Dasar (UUD) 1945.

Selain berperan strategis untuk mendukung pertumbuhan ekonomi yang cukup tinggi secara berkelanjutan dan meningkatkan produktivitas masyarakat, industri juga berperan menciptakan lapangan usaha serta memperluas kesempatan kerja, meningkatkan serta menghemat devisa, mendorong pembangunan daerah, meningkatkan serta memeratakan pendapatan masyarakat dan mengentaskan kemiskinan.Proses industrialisasi dalam pembangunan industri juga penting dalam mendukung berlangsungnya perubahan tata nilai masyarakat dan pranata sosial yang lebih dinamis dan berkualitas Supardi (2003).

Keberadaan industri pada setiap daerah akan membawah perubahan terhadap kehidupan masyarakat sekitarnya. Dimana perubahan kehidupan ini dampak dari meningkatnya kegiatan sosial maupun kegiatan ekonomi dari masyarakat di sekitar industri, tidak terkecuali pula jika industri tersebut adalah industri rumah panggung.

Industri rumah panggung merupakan rumah adat Minahasa yang dalam proses pengerjaannya di lakukan turun temurun oleh masyarakat Minahasa yang khususnya masyaraat Desa Woloan Satu Utara Kecamatan Tomohon Barat. Rumah panggung yang di produksi di Desa Woloaan Satu Utara ini ada bermacam-macam ukuruan yang normalnya $5 \times 6 \mathrm{~m}, 7 \times 9 \mathrm{~m}, 9 \times 12 \mathrm{~m}$ dan lainnya sesuai dengan pesanan, selain bentuk yang bagus juga mempunyai ke istimewaan tersendiri yaitu memakai sisitem knock down atau bongkar pasang jadi unit rumah panggung yang telah selesai, bisa di bongkar lagi dan di pindahkan kelokasi yang sesuai keinginan konsumen. Dalam pengerjaannya pengusaha memberikan upah pada pekerjannya setiap harinya atau upah harian.

Industri rumah panggung di Desa Woloan Satu Utara pada awalnya merupakan usaha sampingan bagi masyarakat untuk mencari pendapatan tambahan lain. Namun, kini banyak yang mulai tertarik untuk mengembangkan industri rumah panggung dibandingkan dengan usaha pertanian karena industri rumah panggung dianggap lebih menguntungkan.

Perkembangan industri rumah panggung di Desa Woloan SatuUtara dipengaruhi oleh beberapa faktor, seperti modal, tenaga kerja, bahan baku, transportasi dan pemasaran. Pengusaha rumah panggung sering dihadapkan pada kesulitan dalam mendapatkan modal, khususnya pada saat membayar upah tenaga kerja.

Oleh sebab itu banyak usaha industri rumah panggung di Desa Woloan Satu Utara yang pekerjanya dari anggota keluarga atau rumahtangga sendiri.Pendapatan dari usaha industri rumah panggung dapat memberikan tambahan pendapatan bagi total pendapatan rumah tangga masyarakat atau pengusaha rumah panggung. Industri rumah panggungselain membuka lapangan pekerjaan jugamemberikan dampak terhadap pendapatan rumah tangga masyarakat Desa Woloan Satu Utara Kecamatan Tomohon Barat dan ini menjadi ide untuk melakukan penelitian.

\section{Perumusan Masalah}

Rumusan masalah adalah bagaimana dampak aktivitas industri rumah panggung terhadap pendapatan rumah tangga masyarakat di Desa Woloan satu kecamatan Tomohon Barat. 


\section{Tujuan}

Tujuan dari penelitian ini adalah mengukur kontribusi industri rumah panggung terhadap pendapatan rumah tangga masyarakat di Desa Woloan Satu Utara Kecamatan Tomohon Barat.

\section{Manfaat Penelitian}

Memberikan informasi, pertimbangan dan masukan terhadap pemerintah terhadap pentingnya Industri Rumah Kayu di Desa Woloan Satu Utara Kecamatan Tomohon Barat yang menyerap banyak tenega kerja juga dan meningkatkan ekonomi masyarakat.

\section{METODE PENELITIAN}

\section{Tempat dan Waktu Penelitian}

Penelitian ini dilakukan di Desa Woloan Satu Kecamatan Tomohon barat, Kota Tomohon Sulawesi Utara, yaitu kawasan industri rumah Panggung. Lokasi ini dipilih karena sesuai dengan rencana penelitian yang dilakukan, dari bulan januari 2015 sampai dengan bulan Februari 2015.

\section{Metode Pengumpulan Data}

Metode pengumpulan data dilakukan dengan metode survey data yang dipakai meliputi data primer dan sekunder. Data primer yaitu data yang di peroleh langsung dari responden yaitu masyarakat desa woloan satu yang bekerja di industri dengan cara mewanwancarai langsung dengan kuisioner. Data sekunder yaitu data yang di peroleh dari kantor kelurahan.

\section{Metode Pengambilan Sampel}

Yang menjadi populasi adalah masyarakat yang menjadi tenaga kerja di industri rumah panggung yaitu anggota rumah tangga. Dari populasi di ambil 30 sampel secara acak (Simple Random Sampling).

\section{Konsep Pengukuran Variabel}

\section{Pendapatan Rumah Tangga}

Total pendapatan yang diterima oleh seluruh anggota rumah tangga yang bekerja baik dalam industri rumah panggung maupun di luar industri rumah panggung di ukur dalam satuan rupiah (Rp/bulan).

2. Pendapatan yang bersumber dari Luar Industri

Pendapatan yang di terima dari luar industri rumah panggung dalam satuan rupiah (Rp/bulan).

3. Pendapatan yang bersumber dari Industri Pendapatan yang di terima dari industri rumah panggung dalam satuan rupiah ( $\mathrm{Rp} / \mathrm{bulan})$.

4. Kontribusi dari Industri Rumah Panggung Pendapatan dari industri rumah panggung di bagi dengan total pendapatan rumah tangga satuan persen $(\%)$.

\section{Jumlah Upah Tenaga Kerja}

Uang yang di berikan oleh pengusaha keapada pekerja setiap hari kerjannya dalam satuan rupiah (Rp/bulan).

\section{Metode Analisis Data}

Metode analisis data yang digunakan adalah analisis data deskriptif kuantitatif dan kualitatif yaitu berupa deskripsi mengenai dampak aktivitas industri rumah panggung terhadap pendapatan rumah tangga masyarakat desa woloan satu utara.

\section{DESKRIPSI WILAYAH PENELITIAN}

\section{Letak Geografis dan Iklim}

Desa Woloan 1 Utara Kecamatan Tomohon Barat, Kota Tomohon Provinsi Sulawesi Utara Luas Wilayah Kelurahan Woloan 1 Utara kurang lebih 151.3 ha dengan batas wilayah :
Sebelah Utara
: Desa Wailan
Sebelah Selatan
: Desa Woloan Satu
Sebelah Timur
: Desa kolongan
Sebelah Barat
: Desa Kolongan Dua 
Kelurahan Woloan 1 Utara berada pada ketinggian $600 \mathrm{~s} / \mathrm{d} 650$ meter dari permukaan laut dengan temperatur udara antara $22^{\circ} \mathrm{c}$ s/d $32^{\circ} \mathrm{c}$, dengan curah hujan rata-rata $\geq 100 \mathrm{Mm} /$ tahun.

\section{Penduduk}

Penduduk desa Woloan 1 Utara berjumlah 1.546 jiwa, dengan kepala keluarga 445 keluarga yang di bagi 6 lingkungan.

\section{Tabel 1. Karakteristik demografi Desa Woloan 1 Utara}

\begin{tabular}{ccc}
\hline No. & Uraian & Jumlah \\
\hline 1 & Lingkungan & 6 buah \\
2 & Penduduk & 1.546 jiwa \\
\hline 3 & Jumlah keluarga & 445 keluarga \\
\hline
\end{tabular}

Sumber : Kantor Kelurahan Woloan 1 Utara. 2015

\section{Mata Pencaharian Penduduk}

Mata pencaharian penduduk Desa Woloan

Satu berbeda-beda seperti pada tabel 2 .

Tabel 2. Mata Pencaharian Penduduk Desa Woloan Satu Utara

\begin{tabular}{lll}
\hline No. & Uraian & Jumlah \\
\hline 1 & $\begin{array}{l}\text { Pengusaha Rumah } \\
\text { Panggung }\end{array}$ & 65 Jiwa \\
2 & $\begin{array}{l}\text { Keluarga Pengusaha } \\
\text { Rumah Panggung }\end{array}$ & 120 Keluarga \\
3 & Pekerja Rumah Pangung & 880 Jiwa \\
4 & Keluarga Pekerja Rumah & 183 Keluarga \\
& Panggung & \\
5 & PNS, ABRI, Pensiunan, & 601 Jiwa \\
& PNS, ABRI dan Pegawai & \\
& Swasta, Petani & \\
\hline 6 & Keluarga PNS, ABRI, & 142 Keluarga \\
& Pensiunan PNS, ABRI dan & \\
& Pegawai Swasta, Petani & \\
\hline
\end{tabular}

Dari Tabel 2 diketahui bahwa sebagian besar penduduk Desa Woloan Satu Utara mempunyai mata pencaharian sebagai pengusaha dan pekerja produksi rumah panggung sebanyak 303 dari jumlah keluarga sebanyak 445 keluarga. Dan Sebanyak 142 keluarga mempunyai mata pencaharian selain pengusaha dan pekerja produksi rumah panggung.

\section{HASIL DAN PEMBAHASAN}

\section{Umur Responden}

Umur responden dalam penelitian ini mempengaruhi kemampuan fisik serta pengalaman tukang dalam melaksanakan pekerjaannya.Tukang yang memiliki umur makin tua makin berpengalaman dan tabel 3 ini menenjukan umur responden

\section{Tabel 3. Jumlah Responden Berdasarkan Umur}

\begin{tabular}{cccc}
\hline No. & $\begin{array}{c}\text { Umur (Ta- } \\
\text { hun) }\end{array}$ & $\begin{array}{c}\text { Jumlah } \\
\text { Responden }\end{array}$ & $\begin{array}{c}\text { Presentase } \\
\%\end{array}$ \\
\hline 1 & $20-30$ & 5 & 16.67 \\
2 & $31-40$ & 10 & 33.33 \\
3 & $41-50$ & 5 & 16.67 \\
4 & $51-60$ & 9 & 30 \\
5 & $>61$ & 1 & 3.33 \\
\hline & Jumlah & 30 & 100 \\
\hline
\end{tabular}

Sumber : Di Olah dari data primer, 2015

Pada tabel 3 di ketahui bahwa jumlah responden yang berada pada umur produktif sebanyak 29 responden. Hal ini menunjukan bahwa responden yang memiliki pengalaman serta fisik yang baik berada pada umur 31-40 atau $33.33 \%$, dimana mereka telah berpengalaman dan memiliki fisik yang baik dalam berusaha produksi rumah panggung. Dalam usia yang produktif serta kemampuan fisik yang baik tentu sangat di butuhkan untuk bekerja dalam industri rumah panggung. Secara umum dapat di katakan bahwa umur responden sangat berperan penting dalam proses pembuatan atau produksi unit rumah panggung. 


\section{Pendidikan Responden}

Pendidikan responden atau tukang sangat penting karna tanpa pendidikan secara otomatis tidak akan dapat mengenal baca, tulis, dan berhitung, kemampuan dalam bekerja akan sangat buruk. Melalui pendidikan tukang akan memimiliki dasar yang berguna dalam proses melakukan pekerjaan serta mengambil keputusan dalam perencanaan pembuatan suatu unit rumah panggung.

\section{Tabel 4. Pendidikan Responden}

\begin{tabular}{cccc}
\hline No. & $\begin{array}{c}\text { Tingkat Pen- } \\
\text { didikan }\end{array}$ & $\begin{array}{c}\text { Jumlah } \\
\text { Responden }\end{array}$ & $\begin{array}{c}\text { Presentase } \\
\%\end{array}$ \\
\hline 1 & SD & 1 & 3.33 \\
2 & SMP & 11 & 36.67 \\
3 & SMA & 18 & 60 \\
\hline & Jumlah & 30 & 100
\end{tabular}

Sumber : dari data primer, 2015

Pada tabel 4 menunjukan bahwa jumlah responden yang berpendidikan SD sebanyak 1 responden atau $3.33 \%$, berpendidikan SMP sebanyak 11 responden atau $36.67 \%$ dan yang berpendidikan SMA sebanyak 18 responden atau 60\%. Dengan tingkat pendidikan tersebut kiranya kemampuan responden dalam bekerja serta menerima informasi dan teknologi sangat baik dalam mengelola produksi rumah panggung.

Pendidikan responden tidak bisa lepas dari kualitas suatu unit rumah panggung dimana ketika seorang tukang yang tidak bersekolah minimal tamatan SD pasti akan kesusahan dalam melakukan perhitungan ketika saat pembuatan atau pemasaran.

\section{Keadaan Ekonomi Rumah Tangga Masyarakat Sebelum dan Sesudah Ada Industri Rumah Panggung}

Rumah panggung adalah rumah adat dari Minahasa yang di turun-temurun oleh nenek moyang, proses pembuatan yang tradisional yang membuat rumah panggung Minahas terkenal sampai keluar negeri, pada awalnya rumah panggung ini adalah rumah tinggal oleh orang tua duluh dimana pekerjaan utama mereka adalah petani dan pekerjaa sampingan mereka adalah membuat rumah panggung untuk di tinggali.

Namun dari tahun ketahun daya tarik dari rumah panggung ini bisa di jadi kan usaha industri, sehingga bisa menaikan ekonomi masyarakat, orang-orang mulai meninggalkan pekerjaan utama mereka sebagai petani dan beralih ke industri rumah pangung, dan pekerjaan petani mereka menjadi sampingan dan yang utama yaitu menjadi tukang di industri rumah panggung.

Modal dalam industri rumah panggung ini adalah modal sendiri, modal kemudian di belikan bahan baku, alat serta membayar gaji pekerja. Untuk memulai proses produksi pemilik usaha atau pengusaha mereka membeli kayu dari suplaier ketika bahan baku kayu tiba proses produksi pun di mulaidari memotong kayu sesuai dengan ukuranukuran yang telah di tentukan menyusun rangka rumah panggung, menyatukan bagian mulai dari lantai dinding pintu dan lain-lain, pemasangan seng dan pengecetan.

\section{Penyerapan Tenaga Kerja Dalam Indsutri Ru- mah Panggung}

Terserapnya tenaga kerja dalam industri rumah panggung di karenakan banyak masyarakat yang putus sekolah dan lokasi untuk bekerja dekat dengan tempat tinggal mereka, pekerjaan sebagai tukang di industri rumah panggung ini sudah turuntemurun dari nenek-moyang di sulawesi utara, itu mengakibatkan masyarakat enggan memilih pekerjaan yang lain mereka akan lebih memilih menjadi tukang selain memliki pengetahuan dalam pertukangan secara otodidak juga gaji atau upah yang di terima terasa cukup, atau sebagai pengusaha yang lebih menguntungkan tapi juga harus memiliki modal yang banyak.

\section{Perubahan Tingkat Upah yang diberikan}

Dari tahun ketahun pasti akan ada perubahan upah yang diberikan oleh pengusaha terhadap pekerja dalam hal ini tukang di industri rumah panggung, jika upah pekerja naik pasti harga dari unit rumah panggung juga akan ikut naik, biasanya pembeli akan memberikan respon, mereka kurang untuk membeli atau bahkan mereka tidak 
akan membeli unit rumah panggung dan pemilik atau produsen akan merugi. Turunya target penjualan akan berakibat pemilik akan mengurangkan pekerja dan akan mengantikan pekerja dengan mesin, jika dengan kondisi upah yang naik kerna hal-hal lain tapi barang-barang modal harga nya tetap. Sebagai pemilik atau produsen harus berhati-hati dan bijak dalam mengambil keputusan.

Ketika banyak peminat atau pembeli unit rumah panggung pemilik atau produsen akan cenderung gencar menambahkan kapasitas produksinya, untuk memenuhi kebutuhan pasar, untuk maksud tersebut pemilik akan menambah penggunaan tenaga kerja disinilah banyak tenaga kerja yang terserap baik yang muda maupun yang tua pemilik industri rumah panggung harus teliti karna bukan sekedar memenuhi kebutuhan pasar tapi juga harus dan bisa memberikan kualitas unit rumah pangung yang bagus.

\section{Pola Pemasaran Hasil Industri "Rumah Panggung"}

Setiap produsen akan berusaha agar produksi yang dihasilkannya dapat terjual dengan harapan agar mendatangkan keuntungan. Oleh karena itu, produsen harus dapat melaksanakan aktivitas usahanya secara maksimal. Salah satu aktivitas yang penting untuk dilakukan adalah melakukan pemasaran dengan baik dan tepat, karena besar kecilnya keuntungan yang diperoleh tergantung pada pola pemasaran yang dilakukan. Pola pemasaran hasil produksi dapat dilihat dari tiga sisi yakni, sistem distribusi produk, kesepakatan harga, dan lingkup pemasaran.

Semakin banyak menggunakan saluran distribusi maka semakin tinggi harga barang bagi konsumen, begitu juga sebaliknya. Sedangkan jika menggunakan penyaluran langsung dari produsen ke konsumenakan dapat menghemat biaya pemasaran. Untuk industri rumah pangung sebagian besar menggunakan sistem penyaluran langsung sebab kebanyakan dari konsumen yang mendatangi dan memesan kepada pengerajin industri, artinya pengerajin tersebut langsung bertransaksi dengan konsumen. Untuk sistem kesepakatan harga dari hasil produksi dilakukan dengan sistem kesepakatan kedua belah pihak, artinya terjadi tawar mena- war antara produsen dan konsumen demi tercapainya kepuasan antara keduanya.

Lingkup pemasaran hasil produksi industri sebagian besar mencangkup dalam daerah sendiri saja. Hampir di seluruh Sulawesi Utara menjadi lingkup pemasaran industri kerajinan. Selain mencangkup tingkat region, lingkup pemasaran industri kerajinan juga mencapai pasar inter-region, seperti Kalimatan, Jawa, Malaysia, dll. Hal tersebut menunjukkan bahwa industri kerajinan sudah dikenal di mata dunia. Jadi secara umum pola pemasaran tidak mengalami kendala.

\section{Tenaga Kerja}

Tenaga kerja dalam industri kerajinan rumah panggung ini keseluruhan berjenis kelamin laki-laki. Dalam industri kerajinan rumah panggung sebagian besar pengerajin ikut terjun langsung dalam industri kerajinan itu sendiri. Hasil penelitian menunjukkan bahwa semua pekerja berasal dari Desa Woloan Satu Utaratenaga kerja dalam industri kerajinan dari masyarakat Desa sendiri, hal tesebut menunjukkan bahwa industri kerajinan memanfaatkan sumber daya manusia yang terdapat di dalam Desa tersebut.

Keadaan tersebut akan berdampak positif, sebab hal tersebut akan mengurangi jumlah pengangguran yang terdapat di Desa. Terdapat pula variasi antar lingkungan dari lingkungan I - VI. Jumlah tenaga kerja dalam setiap industri kerajinan bervariasi antar industri. Dari hasil penelitian diketahui sebagian besar jumlah tenaga kerja industri kerajinan berjumlah 5 orang keatas.

\section{Tingkat Pendapatan Masyarakat Sekitar Lokasi Industri Rumah panggung}

Pendapatan masyarakat yang berada di sekitar lokasi industri rumah panggung bisa di artikan sebagai peneriamaan yang berupa penghasilan yang diterima oleh keluarga setiap bulan, seperti berikut : 
Tabel 5. Tingkat Pendapatan Masyarakat Sekitar Lokasi Industri Rumah panggung

\begin{tabular}{lccc}
\hline No. & $\begin{array}{c}\text { Pendapatan Total } \\
\text { Keluarga Setiap } \\
\text { Bulan (Rp) }\end{array}$ & $\begin{array}{c}\text { Jumlah } \\
\text { Responden } \\
(\mathrm{KK})\end{array}$ & $\begin{array}{c}\text { Persentase } \\
(\%)\end{array}$ \\
\hline 1 & $2.000 .000-$ & 25 & 84 \\
& 3.000 .000 & & \\
2 & $3.000 .000-$ & 3 & 10 \\
& 4.000 .000 & & 3 \\
3 & $4.000 .000-$ & 1 & 3 \\
4 & 5.000 .000 & & 100 \\
\hline & $5.000 .000>$ & 1 &
\end{tabular}

Sumber : di olah dari data primer, 2015

Berdasarkan tabel 5 diketahui dari 30 responden $25 \mathrm{kk}$ atau $84 \%$ yang berpendapatan $\mathrm{Rp}$ 2.000.000 - Rp 3.000.000, $3 \mathrm{kk}$ atau $10 \%$ memiliki pendapatan antara Rp 3.000.000 - Rp 4.000.000, 1 kk atau $3 \%$ berpendapatan Rp 4.000.000 - Rp 5.000.000, dan $1 \mathrm{kk}$ atau $3 \mathrm{Rp} 5.000 .000$ lebih. berdasarkan data tersebut menunjukan mayoritas 30 responden dari keseluruhan masyarakat sekitar lokasi industri rumah panggung adalah memiliki ratarata pendapatan antara $\mathrm{Rp} 2.000 .000-\mathrm{Rp}$ 3.000.000 perbulan, sedangkan minoritas adalah $\mathrm{Rp}$ 4.000.000 - Rp 5.000.000 perbulan.

Tingkat pendapatan masyarakat sekitar lokasi industri rumah panggung, yaitu pendapatan setiap bulannya keluarga responden yang tiggal di sekitar lokasi industri rumah panggung yang mana anggota keluarganya bekerja di industri rumah pangung dan lainya.

\section{Jumlah Anggota Keluarga yang Bekerja}

Umumnya keluarga adalah semua orang yang bertempat tinggal dalam satu rumah yang mana terdiri atas kepala keluarga, istri, anak, dan sanak saudara. Mereka yang tinggal bersama dalam satu atap merupakan tanggungan kepala keluarga atau tanggungan bersama-sama. Sedangkan Jumlah anggota keluarga yang bekerja maksudnya adalah banyaknya jumlah anggota keluarga yang memiliki pekerjaan. Jadi di dalam satu keluarga ada lebih dari satu orang yang memiliki pekerjaan.
Dimana pekerjaan yang dimiliki tersebut juga memberikan sumbangan pada pendapatan keluarga atau bisa dikatakan bahwa anggota keluarga yang juga bekerja menanggung kebutuhan keluarga bersama. Responden atau masyarakat yang berada di sekitar lokasi industri rumah panggung tersebut.

Tabel 6. Jumlah anggota keluarga responden yang bekerja

\begin{tabular}{cccc}
\hline No. & $\begin{array}{c}\text { Jumlah } \\
\text { anggota } \\
\text { keluarga } \\
\text { yang bekerja }\end{array}$ & $\begin{array}{c}\text { Jumlah } \\
\text { responden }\end{array}$ & $\begin{array}{c}\text { Persentase } \\
(\%)\end{array}$ \\
\hline 1 & 1 & 22 & 73,34 \\
2 & 2 & 7 & 23,33 \\
3 & 3 & 1 & 3,33 \\
\hline & Jumlah & 30 & 100 \\
\hline
\end{tabular}

Sumber : di olah dari data primer, 2015

Dari tabel 6diketahui bahwa 22 responden atau $73,34 \%$ yang anggota keluarganya hanya kepala keluarga saja yang bekerja, kemudian ada 7 atau $23,33 \%$ yang anggota keluarganya memiliki pekerjaan berjumlah 2 orang, kemudian ada 1 atau 3,33 $\%$ responden sebanyak 3 orang dalam keluarga yang memiliki pekerjaan. Dengan begitu menjelaskan bahwa mayoritas dari masyarakat di sekitar lokasi industri rumah panggung hanya 1 orang yag memiliki pekerjaan atau hanya kepala keluar saja yang bekerja.

jumlah anggota keluarga yang bekerja, yang mana siapa saja yang dalam keluarga yang memiliki pekerjaan baik bekerja di industri rumah panggung maupun di luar industri rumah panggung ketika banyak anggota keluarga yang sudah memiliki pekerjaan, rumah tangga itu akan menjadi lebih sejahtra daripada rumah tangga yang memiliki sedikit anggota keluarga yang sudah bekerja karena pendapatan rumah tangga lebih kecil.

\section{Pendapatan Rumah Tangga}

Setiap rumah tangga harus memenuhi kebutuhan anngota rumah tannganya untuk kelangsungan hidup. Pendapatan rumah tangga yaitu total pendapatan diterimah oleh responden serta seluruh 
anggota rumah tangganya baik yang bekerja dalam industri rumah panggung maupun yang bekerja di luar industri rumah panggung.

Tabel 7. Rata-rata Pendapatan Rumah Tangga Responden

\begin{tabular}{cc}
\hline & $\begin{array}{l}\text { Rumah Tangga } \\
\text { Responden (30 } \\
\text { Responden) }\end{array}$ \\
\hline $\begin{array}{c}\text { Total Pendapatan } \\
\text { Rumah tangga }\end{array}$ & 92.520 .000 \\
\hline $\begin{array}{l}\text { Rata-rata Pendapatan } \\
\text { Rumah tangga }\end{array}$ & 3.084 .000 \\
\hline
\end{tabular}

Sumber : di olah dari data primer, 2015

Dari tabel 7. Diketahui bahwa total pendapatan rumah tangga responden adalah $\mathrm{Rp} 92.520 .000$ dan jumlah rata-rata yang di terima adalah $\mathrm{Rp}$ 3.084.000 setiap bulan.

\section{Pendapatan yang Bersumber dari Luar Industri Rumah Panggung}

Selain dari industri rumah panggung pendapatan yang di terimah olah anggota rumah tangga responden yang menjadi sampel, mereka juga menerima pendapata dari luar industri seperti menjadi tukang cuci, mengojek, bekerja di swasta atau bertani.

Tabel 8. Pendapatan yang Bersumber dari Luar Industri

Rata-rata Pendapatan yang bersumber dari luar
industri (Rp/Bulan)

\begin{tabular}{cc}
\hline Anggota Keluarga & Rata-rata Pendapatan \\
\hline Ayah & 400.000 \\
Ibu & 24.000 \\
Anak & 73.333 \\
\hline Total & 497.333
\end{tabular}

Sumber : di olah dari data primer, 2015

Dari tabel 8. Diketahui rata-rata pendapatan yang di terima ayah sebesar

Rp 400.000 pendapatan yang bersumber dari luar industri yang diterima sedikit karena dalam penelitian diketahui mereka menyiapkan 1 hari untuk bekerja di luar industri rumah panggung, sumber pendapatan utama mereka adalah sebagai tukang di industri rumah panggung dan pendapatan sampingan mereka adalah bekerja di luar industri di hari mereka tidak bekerja di industri rumah panggung atau mengolah hasil pertanian mereka untuk keperluan sendiri tidak untuk di jual.

Ibu sebesar Rp 24.000 pendapatan ibu tergolong sedikit di sebabkan, mereka tidak bekerja atau hanya sebagai IRT, hanya sebagian kecil saja yang bekerja seperti menjadi tukang cuci dan lain-lain, dan anak dengan rata-rata pendapatan Rp 73.333 setiap bulanya.

Anak dari responden yang bekerja di luar industri hanya menerima rata-rata pendapatan yang sangat kecil di karenakan mereka sebagian besar belum cukup umur untuk bersekolah, bekerja dan sebagian kecil saja yang sudah bekerja di industri rumah panggung maupun di luar industri rumah panggung. Total rata-rata yang diterimah adalah $\mathrm{Rp}$ 497.333 setiap bulannya.

\section{Pendapatan yang Bersumber dari Industri Rumah Panggung}

Pekerjaan utama responden yaitu sebagai pekerja di industri rumah panggung. Upah pekerja dilihat dari pengalaman tukang semakin berpengalaman semakin besar upah yang diterimanya dari industri rumah panggung, pemberian upah menggunakan sistem upah harian tapi diberikan setiap minggunya yaitu sebesar $\mathrm{Rp}$ 115.000, Rp 125.000, dan Rp 130.000. Jika di konfersikan perminggu yaitu sebesar Rp 575.000, Rp 625.000, dan Rp 650.000. Dan jika perbulanya $R p \quad 2.300 .000, \quad R p 2.500 .000$, dan $R p$ 2.600.000. Rata-rata pendapatan responden setiap bulanya. 
Tabel 9. Pendapatan yang Bersumber dari Industri

\section{Rata-rata Pendapatan yang bersumber dari industri (Rp/Bulan)}

\begin{tabular}{cc}
\hline $\begin{array}{c}\text { Anggota } \\
\text { Keluarga }\end{array}$ & Rata-rata Pendapatan \\
\hline Ayah & 2.280 .000 \\
Ibu & 0 \\
Anak & 306.666 \\
\hline Total & 2.586 .666 \\
\hline
\end{tabular}

Sumber : diolah dari data primer, 2015

dari tabel 9 dapat dilihat jumlah rata-rata pendapatan yang paling besar adalah ayah yaitu sebesar Rp 2.280.000 setiap bulannya, di karenakan pendapatan utama mereka adalah sebagai tukang di industri rumah panggung, mereka bekerja mulai dari jam 8 pagi s/d jam 4 sore dengan istirahat jam $11 \mathrm{~s} / \mathrm{d}$ jam 1 siang.

Ibu tidak bekerja dalam industri rumah panggung karena tidak memiliki pengetahuan dalam bertukang dan tidak memiliki kekuatan yang cukup untuk bekerja, dan anak rata-rata pendapa$\tan$ Rp 306.666 setiap bulan, hanya sebagian kecil saja anak bekerja di industri rumah panggung, mereka belum cukup umur untuk bekerja dan sebagian besar masih bersekolah. Total rata-rata pendaptan yang bersumber dari industri rumah panggung adalah Rp 2.586 .666 setiap bulannya.

\section{Kontribusi dari Industri Rumah Panggung}

Persentase pendapatan yang bersumber dari industri rumah panggung dan luar industri rumah panggung, dimana pendapatan mana yang lebih besar kontribusinya bagi rumah tangga, dapat di lihat pada tabel 9 .
Tabel 10. Kontribusi Pendapatan Dari Industri Rumah Panggung

\begin{tabular}{ccc}
\hline $\begin{array}{c}\text { Sumber Pen- } \\
\text { dapatan }\end{array}$ & $\begin{array}{c}\text { Rata- rata } \\
\text { Jumlah Pendapatan } \\
\text { (Rp/Bulan) }\end{array}$ & $\begin{array}{c}\text { Kontribusi } \\
(\%)\end{array}$ \\
\hline $\begin{array}{c}\text { Industri Ru- } \\
\text { mah } \\
\text { panggung }\end{array}$ & 2.586 .666 & $84 \%$ \\
$\begin{array}{c}\text { Luar Industri } \\
\text { Rumah }\end{array}$ & 497.333 & $16 \%$ \\
Panggung & & \\
\hline Total & 3.083 .999 & $100 \%$ \\
\hline
\end{tabular}

Sumber : diolah dari data primer, 2015

Responden yang mulanya pekerjaan utama di bidang pertanian atau perkebunan, kurang memberikan kontribusi hasil atau pendapatan untuk rumah tagganya. Pekerjaan mereka di bidang industri rumah panggung awalnya hanya merupakan pekerjaan sampingan saja tapi lama-kelamaan menjadi pekerjaan utama karenamemberikan kontribusi hasil dan pendapatan yang lebih besar di bandingkan dengan pertanian.

Sekarang pekerjaan utama masyarakat atau responden yang dulunya petani menjadi tukang di industri rumah panggung. Dari tabel 10 diketahui bahwa industri rumah panggung merupakan pendapatan utama responden dengan kontribusi sebesar $84 \%$, dan luar industri $16 \%$.

\section{KESIMPULAN DAN SARAN}

\section{Kesimpulan}

Berdasarkan hasil penelitian di Desa Woloan I Utara Kecamatan Tomohon Barat Kota Tomohon dapat disimpulkan sebagai berikut :

Pada awalnya pekejaan utama responden di bidang pertanian kurang dalam memberikan kontribusi hasil dan pendapatan bagi rumah tangga responden, sementara pekerjaan sampingan sebagai tukang di industri rumah panggung lebih besar memberikan kontribusihasil dan pendapatan se- 
hingga masyarakat menjadikan pekerjaan sampingan sebagai pekerjaan utama.

Pendapatan tenaga kerja atau responden di industri rumah panggung lebih baik dari pada sebagai petani sehingga mereka lebih memilih bekerja di industri dari pada di pertanian atau lainya.

\section{Saran}

Diperlukan adanya perhatian dari pemerintah terhadap perkembangindustri rumah pangung sehingga bisa lebih memberikan kontribusi pendapatan terhadap rumah tangga masyarakat juga terhadap penyerapan tenaga kerja di Desa Woloan Satu Utara.

Selain itu diharapkan bagi pemerintah Kota Tomohon untuk lebih meningkatkan kualitas sumber daya manusia untuk mendukung dalam pembangunan daerah.

\section{DAFTAR PUSTAKA}

Agusmidha.2010. Dinamika Hukaum Ketenagakerjaam Indonesia. Usu Press. Medan.

Alam, S. 2006. Ekonomi Jilid 1. Esis. Semarang.

Aripin. Z. 2010. Skripsi.Analisis Harga Pokok Produksi Tahu -Ttempe pada Home Industri Lela Jaya Manna, Bengkulu Selatan. Jurusan Manajemen Fakultas Ekonomi dan Bisnis Universitas Bengkulu.

Ayu Fitria. F. 2008. Skripsi.Analisis Partisipasi Dan Kontribusi Pendapatan Tenaga Kerja Wanita Pada Industri Kecil Krupuk Kedelaidi Kecamatan Tuntang Kabupaten Semarang. Fakultas Pertanian Universitas Sebelas Maret Surakarta.

Girindea. K. 2012. Skripsi.Analisis Pengaruh Persepsi Harga, Promosi, Distribusi, Kualitas Produk, dan Segmentasi Pasar Terhadap Keberhasilan Produk Sepeda Motor Yamaha di Kota Semarang (Studi Kasus pada Dealer Yamaha Motor Agung Semarang). Fakultas Ekonomika dan Bisnis Universitas Diponegoro Semarang

Gustarina.E 2014.Skripsi.Upaya Meningkatkan Aktivitas Dan Hasil Belajar Siswa Dalam Pembelajaran Tematik Dengan Menerapkan Model Picture and Program Studi Pendidikan Guru
Sekolah Dasar. Jurusan Ilmu Pendidikan Fakultas Keguruan Dan Ilmu Pendidikan Universitas Bengkulu.

Hutabarat. L. 2010. Pengaruh PDB Sektor Industri Terhadap Kualitas Lingkungan Ditinjau dari Emisi Sulfur dan CO2 di Lima Negara Anggota ASEAN Periode 1980-2000.Skripsi.Fakultas Ekonomi Universitas Diponegoro Semarang

Ir. Shinta. A, M.P. 2011.Manajemen Pemasaran. UB Press. Malang.

Kristanto, P. 2004. Ekologi Industri. Andi Offset. Yogyakarta.

Munifa. 2013. Skripsi. Analisis Tingkat Pendapatan Masyarakat Sekitar PTPN XI Pabrik Gula Padjarakan Kecamtan Pajajaran Kabupaten Probolinggo. Jurusan Ilmu Ekonomi dan Studi Pembangunan Fakultas Ekonomi Univesitas Jember.

Nababan. C. D. 2009. Analisis Faktor-Faktor Yang Mempengaruhi Pendapatan Petani Jagung Di Kecamatan Tiga Binanga Kabupaten Karo.Skripsi. Universitas Sumatra Utara

Nain, Ahmad. S. M dan Yusoff, R. MD. 2003 Konsep, Teori, Dimensi dan Isu Pembangunan Edisi 3. Universiti Teknologi Malaysia. Malaysia.

Pelle C.M. 2012. Skripsi.Potensi Tabungan Rumah Tangga Petani Di Desa Poopo Utara Kecamatan Ranoyapo. Fakultas Pertanian Universitas Sam Ratulangi Manado.

Saputri, O. D. 2011. Analisis Penyerapan Tenaga Kerja Di Kota Salatiga.Skripsi.Fakultas Ekonomi Universitas Diponegoro Semarang.

Supartama.M dkk 2013.Analisis Pendapatan Dan Kelayakan Usahatani Padi Sawah Di Subak Baturiti Desa Balinggi Kecamatan Balinggi Kabupaten Parigi Moutong. Jurnal. Agrotekbis 1 (2) : 166-172, Juni 2013 ISSN : 2338-3011.

Supardi, I. 2003. Lingkungan Hidup dan Kelestariannya.Cetakan Ke-3.PT Alumni. Bandung.

Saputro. R. A. 2014. Skripsi.Analisis Sektor UKM Terhadap Penyerapan Tenaga Kerja di Provinsi D.I. Yogyakarta. Fakultas Ekonomika dan Bisnis Universitas Diponegoro Semarang

Tohar. M. 2000. Membuka usaha kecil.Kanisius.Yogyakarta.Isbn 979-672568-1 
ASE - Volume 11 Nomor 2, Mei 2015: 41 - 51

Uria D. 2009.Skripsi.Produktifitas tenaga Kerja Sektor Pertanian Di Kab. Bolaang Mongondow. Fakultas Pertanian Universitas Sam Ratulangi Manado.
Widyatmanti, W dan Dini Natalia. 2006. Goegrafi. Grasindo, jakarta. 